\title{
Sarcoma of the Orbit Pathologic Primary Tumor TNM Finding v7
}

National Cancer Institute

\section{Source}

National Cancer Institute. Sarcoma of the Orbit Pathologic Primary Tumor TNM Finding v7. NCl Thesaurus. Code C88810.

A pathologic finding about one or more characteristics of sarcoma of the orbit, following the rules of the TNM AJCC V7 classification system as they pertain to staging of the primary tumor. 